\title{
Deteksi dan Intervensi Dini Pada Anak Autis
}

\author{
Sri Muji Rahayu \\ pamardiputra@yahoo.co.id \\ SLB Pamardi Putra, Bantul
}

\begin{abstract}
Abstrak
Autism adalah suatu gangguan perkembangan secara menyeluruh yang mengakibatkan hambatan dalam kemampuan sosialisasi, komunikasi, dan juga perilaku. Gangguan tersebut dari taraf yang ringan sampai dengan taraf yang berat. Gejala autis ini pada umumnya muncul sebelum anak mencapai usia 3 tahun. Pada umumnya penyandang autis mengacuhkan suara, penglihatan ataupun kejadian yang melibatkan mereka, dan mereka menghindari atau tidak merespon kontak sosial misalnya pandangan mata, sentuhan kasih sayang, bermain dengan anak lainnya. Gangguan yang dialami anak autism adalah gangguan dalam bidang interaksi sosial, gangguan dalam bidang komunikasi (verbal-non verbal), gangguan dalam bidang perilaku, gangguan bidang perasaan/emosi, dan gangguan dalam bidang persepsi-sensorik. Penanganan anak autis bertujuan agar perkembangan yang terlambat pada dirinya dapat diatasi sesuai dengan perkembangan usianya. Semakin cepat mengetahui anak mengalami autis, maka akan semakin cepat pula usaha penanganannya. Deteksi dan intervensi dini sangat penting untuk anak autis sehingga penanganannnya lebih cepat dilakukan dan tidak membutuhkan waktu yang relatif lama. Terapi untuk anak autis harus dimulai sejak awal dan harus diarahkan pada hambatan maupun keterlambatan yang secara umum dimiliki oleh setiap anak.
\end{abstract}

Kata kunci: deteksi, intervensi, autis

\begin{abstract}
Autism is a completely development interference that cause barriers in social skills, communication, and also behavior. The interference is from light level until heavy level. This symptom of autism generally appear before the child reaches three years old. Generally autism not care with the voice, sight or events involving their, and they don't respond and avoid social contact such as eyesight, touch of love, play with others. The interference experienced by autism is interference in social interaction, interference in communication (verbal- non verbal), interference in attitude, and the interference in sensory perception. Handling children with autism aims in order to late development on him/her can be overcome according with their age development. Sooner know the child has autism, so will quickly attempt to handle. Detecting and early interfention is very important for autism so to handle it quicker to do and does not need much time is relatively long. Theraphy for children with autism must start early and should be directed at the obstacles and tardiness that are common possessed by child.
\end{abstract}

Keywords: detecting, intervention, autism 


\section{Pendahuluan}

Dalam dunia anak, pendidikan dan kedokteran, kita sering mendengar istilah anak autis. Autisme dapat dialami oleh anak dari setiap ras, suku, strata sosial dan ekonomi. Autis berasal dari bahasa Yunani yaitu autos yang berarti sendiri yang memiliki makna berada dalam dunianya sendiri. Pemakaian istilah autis pertama kali diperkenalkan oleh Leo Kanner seorang psikiater pada tahun 1943. Leo Kannner mengadakan pengamatan terhadap 11 anak yang menunjukkan gejala kesulitan berhubungan dengan orang lain, mengisolasi diri, perilaku yang tidak biasa dan cara berkomunikasi yang aneh.

Autism adalah suatu gangguan perkembangan secara menyeluruh yang mengakibatkan hambatan dalam kemampuan sosialisasi, komunikasi, dan juga perilaku. Gangguan tersebut dari taraf yang ringan sampai dengan taraf yang berat. Gejala autis ini pada umumnya muncul sebelum anak mencapai usia 3 tahun. Pada umumnya penyandang autis mengacuhkan suara, penglihatan ataupun kejadian yang melibatkan mereka, dan mereka menghindari atau tidak merespon kontak sosial misalnya pandangan mata, sentuhan kasih sayang, bermain dengan anak.

Penyebab autism sampai saat ini belum diketahui secara pasti. Beberapa penelitian menyebutkan penyebab autism adalah adanya gangguan pada fungsi susunan syaraf pusat yang diakibatkan karena kelainan struktur otak. Ahli yang lain menyimpulkan bahwa penyebab autism adalah karena kombinasi makanan yang salah atau lingkungan yang terkontaminasi zat-zat beracun yang mengakibatkan kerusakan pada usus besar yang mengakibatkan masalah dalam tingkah laku dan fisik termasuk autism.

\section{Penyebab Autis}

Penyebab autis sangat kompleks, yang telah diketahui sekarang adalah karena adanya gangguan pada fungsi susunan syaraf pusat. Gangguan fungsi ini diakibatkan karena kelainan struktur otak yang mungkin terjadi pada saat janin usia dibawah 3 bulan. Ibu mungkin mengidap virus TORCH (tokso, rubella, cytomegali, herpes), mengkonsumsi makanan yang mengandung zat kimia yang mengganggu pertumbuhan sel otak, menghirup udara beracun, mengalami pendarahan hebat. Faktor genetik juga memegang peran terhadap munculnya autism. Diperkirakan kehidupan manusia yang terlalu banyak memakai zat kimia beracun dapat menyebabkan mutasi kelainan genetik. Pencernaan yang buruk juga memegang peran yang.penting, seringkali adanya jamur yang terlalu banyak di usus sehingga menghambat sekresi enzim. Usus tidak dapat menyerap sari-sari makanan tetapi berubah menjadi "morfin" yang mempengaruhi perkembangan anak.

Beberapa gejala yang dapat diamati dan perlu diwaspadai menurut usia adalah: Usia 0 - 6 tahun

1. Bayi nampak terlalu tenang.

2. Terlalu sensitif, cepat terganggu/terusik.

3. Gerakan tangan dan kaki berlebihan terutama bila mandi.

4. Tidak pernah terjadi kontak mata atau senyum secara sosial.

5. Bila digendong mengepal tangan atau menegangkan kaki secara berlebihan.

Usia 6 - 12 bulan

1. Kalau digendong kaku atau tegang.

2. Tidak tertarik pada mainan.

3. Tidak bereaksi terhadap suara atau kata.

4. Selalu memandang suatu benda atau tangannya sendiri secara lama (akibat terlambat dalam perkembangan motorik halus dan kasar)

Usia 2-3 tahun

1. Tidak berminat atau bersosialisasi terhadap anak-anak lain.

2. Tidak ada kontak mata.

3. Tidak pernah fokus.

4. Kaku terhadap orang lain.

5. Senang digendong dan malas menggerakkan tubuhnya. 
Usia 4- 5 tahun

1. Suka berteriak-teriak

2. Suka membeo atau menirukan suara orang atau mengeluarkan suara-suara aneh.

3. Gampang marah atau emosi apabila rutinitasnya diganggu dan kemaunnya tidak dituruti.

4. Agresif dan mudah menyakiti diri sendiri.

\section{Gangguan Anak Autis}

Gangguan yang dialami anak autism adalah gangguan dalam bidang interaksi sosial, gangguan dalam bidang komunikasi (verbal-non verbal), gangguan dalam bidang perilaku, gangguan bidang perasaan/emosi, dan gangguan dalam bidang persepsisensorik.

A. Gangguan dalam bidang interaksi sosial Gangguan dalam bidang interaksi sosial ditunjukkan dengan :

1. Tidak adanya kontak mata dengan lawan bicara.

2. Ekspresi wajah tidak sesuai dengan perasaan misalnya ketika seharusnya anak mengekspresikan kesedihan namun anak menunjukkan ekspresi gembira misalnya tersenyum.

3. Gerakan atau sikap tubuh tidak sesuai dengan pembicaraan yang sedang berlangsung misalnya anak tersebut seharusnya menolak dengan menggelengkan kepala, namun anak melakukan gerakan menggangguk.

4. Mengalami kesulitan untuk menjalin hubungan dengan teman sebaya yang sesuai dengan usianya, mengalami kesulitan dalam aktivitas dan minat yang melibatkan orang lain, mengalami kesulitan dalam melakukan hubungan timbal balik dengan orang lain.

5. Menolak untuk dipeluk, disentuh, dan digendong.

6. Tidak mau menengok apabila dipanggil.

B. Gangguan dalam bidang komunikasi (verbal-non verbal)
1. Mengalami keterlambatan dalam perkembangan bicara, atau kemampuan bicara.

2. Meracau dengan bahasa aneh.

3. Bicara tetapi tidak digunakan untuk komunikasi.

4. Echolalia/membeo/meniru.

5. Menarik tangan orang dewasa untuk minta tolong.

C. Gangguan dalam bidang perilaku

1. Mengalami gangguan perilaku berlebihan, hiperaktivitas motorik, misal tidak bisa diam, lari tidak terarah, melompat-lompat, berputarputar, handflapping/mengibasngibaskan tangan, gerakan diulangulang.

2. Duduk diam, bengong, tatapan mata kosong, terpaku pada benda yang berputar dan tidak beranjak. Lekat pada benda tertentu.

D. Gangguan dalam bidang perasaan/emosi

1. Tidak ada atau kurang empati.

Misalnya melihat anak menangis ia tidak merasa kasihan melainkan terganggu dengan suaranya dan justru tutup telinga, atau anak itu didatangi dan dipukul.

2. Tertawa-tawa sendiri, menangis, atau marah-marah tanpa sebab yang jelas.

3. Sering mengamuk atau tantrum apabila tidak mendapat yang diinginkan, bisa menjadi agresif dan destruktif atau merusak.

E. Gangguan dalam bidang persespsi sensori

1. Mencium-cium, menggigit atau menjilati mainan atau benda apa saja.

2. Bila mendengar suara keras langsung tutup telinga.

3. Tidak suka disentuh/sangat sensitif.

4. Merasa sangat tidak nyaman apabila memakai baju atau celana dari bahan kasar. 


\section{Karakteristik Anak Autis}

Karakteristik autis yang sering muncul pada masa anak-anak diantaranya adalah:

1. Perkembangan terlambat.

Anak dengan gangguan autism memiliki perkembangan motorik kasar dan motorik halus yang tidak seimbang. Misalnya anak dengan usia 4 tahun memiliki kemampuan motorik kasar yang baik, ia sangat aktif dan terampil bergerak, berlari, melompat, dan memanjat namun ia mengalami hambatan dalam motorik halus seperti mewarnai gambar atau menggambar bentuk bangun sederhana misalnya lingkaran, kotak.

Anak autis juga mengalami hambatan dalam memahami instruksi dan meniru. Anak seolah-olah tidak dapat memberikan atau tidak dapat mendengar apa yang telah disampaikan oleh guru. Anak autis mengalami keterlambatan dalam hal bicara dan bahasa. Anak autis tidak tertarik dengan kehadiran orang lain. Anak dengan gangguan autis mengalami kesulitan dalam melakukan hubungan komunikasi dengan orang disekitarnya. Anak autis cenderung memiliki hambatan dalam bicara dan bahasa sehingga mereka mengalami keterlambatan dalam hal bicara dan bahasa. Bahasa yang digunakan anak autis biasanya tidak lazim atau aneh bahkan ada yang mengatakan bahasa yang digunakan anak autis adalah bahasa planet.

Pada tahap perkembangan selanjutnya anak autis juga akan mengalami hambatan dalam menjalin hubungan dengan teman sebaya, mengalami kesulitan dalam mengekspresikan dan menilai emosi orang lain. Pada saat memasuki hari pertama sekolah anak senang menyendiri dan tidak peduli dengan orang di sekitarnya. Hambatan dalam melakukan komunikasi ini membuat anak senang bermain sendiri, dan mereka merasa punya dunia sendiri.
2. Memiliki rasa ketertarikan pada benda yang berlebihan

Pada anak autis banyak ditemui bahwa diantara mereka banyak yang lebih tertarik pada benda dari pada orang di sekelilingnya. Anak autis mampu mengamati benda dalam waktu yang relatif lama yaitu bisa sepanjang waktu, bisa bermain dengan benda yang dipegang atau diamatinya sambil tertawa bahkan dapat memiliki rasa marah terhadap benda.

3. Menolak ketika dipeluk

Anak autis akan memberikan reaksi penolakan ketika ada orang lain yang akan memeluknya. Ketika anak dipeluk mereka akan menunjukkan reaksi penolakan misalnya menangis atau berteriak-teriak.

4. Memiliki kelainan sensoris

Anak autis cenderung memiliki kelainan sensoris misalnya anak akan menunjukkan kemarahan yang tinggi hingga meledak-ledak apabila keinginannya tidak dipenuhi, beberapa anak autis ada yang sering melukai dirinya sendiri, misalnya membenturkan kepala ke dinding dan anak tidak merasakan kesakitan Ada beberapa anak autis yang memaknai pelukan atau belaian dan sentuhan sebagai sesuatu yang menyakitkan, Suara yang berasal dari banyak orang di sekitarnya memberikan efek menyakitkan sehingga membuat anak autis menangis atau berteriak-teriak.

5. Memiliki kecenderungan melakukan perilaku yang diulang-ulang

Anak autis memiliki kecenderungan melakukan gerakan yang berulangulang, seperti bertepuk tangan, memutar tangan. Apabila anak melakukan kegiatan tersebut maka anak akan mengulangi perbuatan tersebut. Anak autis mengalami hambatan dalam melakukan permainan yang beragam, mereka hanya fokus pada satu permainan saja. Apabila permainan diganti maka anak autis tidak akan merespon. 
Anak-anak autis memiliki kecenderungan untuk melakukan kegiatan yang sifatnya rutin, mereka sulit untuk menerima perubahan tingkah laku. Anak autis akan marah apabila sebuah kebiasaan dirubah.

Menurut Wenar (1994) yang dikutip oleh Eko Handayani (2008) menjelaskan jalannya perkembangan pada penderita autis sebagai berikut:

\section{a. Infant}

Pada bayi yang didiagnosis autism, perilaku-perilaku berikut ini tidak muncul atau terlambat muncul atau salah secara kualitatif: kontak mata, antisipasi posisi tubuh saat akan dipeluk atau digendong, tersenyum pada orang yang dikenal, mulai berkata-kata, kecemasan terhadap orang baru, tertarik pada permainan yang menarik, sperti ci-lukba dan merespon terhadap suara. Selain itu tubuh bayi biasanya kaku dan sulit untuk dipeluk.

b. Toddler/Preschooler

Anak autis memperlihatkan sedikit sekali respon social yang positif. Mereka tidak mengikuti atau menyambut orang tuanya, tidak mencium, memeluk atau dating mengadu pada orang tua saat mereka terluka. Akan tetapi mereka juga tidak menghindar atau menjauhi orang tuanya. Perkembangan bahasanya terlambat, babbling tidak kaya dan tidak bervariasi seperti anak normal. Pengertian terhadap bahasa bahasa juga bermasalah, anak akan mengikuti suatu perintah sederhana hanya jika diikuti dengan gerak tubuh (gesture), itu pun dua arah. Anak sulit untuk melakukan imitasi sosial, misalnya melambaikan tangan sambil berkata "da ..da", serta tidak melakukan permainan "pura-pura atau bermain peran"

c. Middle Chilhood

Anak autis cenderung untuk tidak punya teman, tidak kooperatif dan tidak memiliki empati. Respon sosial yang ditampilkan sering tidak cocok. Aktifitas yang dilakukan merupakan suatu ritual yang sulit diubah.

\section{d. Adolescence}

Masa remaja merupakan saat perkembangan yang dramatik. Mereka mulai menyadari bahwa perilaku mereka berbeda dengan orang lain dan memerlukan usaha yang besar untuk dapat berperilaku sesuai kebiasaan yang berlaku. Biasanya mereka belajar aturan tentang perilaku yang dapat diterima. Bahasa mereka sianggap sebagai "pembicaraan orang asing" yang kurang menguasai bahasa tersebut, akan tetapi masih dapat menggunakannya. Bekerja dan bermain dipelajari melalui rutinitas tanpa variasi dan improvisasi.

e. Adult

Setelah menyadari dan mempelajari lingkungan sekitar, mereka mulai mengerti hukum. Dalam kesehariannya mereka mencoba mematuhi hukum yang berlaku.

\section{Menegakkan Diagnosa}

Mendiagnosis autis membutuhkan kecermatan, pengalaman dan waktu yang relatif lama untuk pengamatan. Selama ini belum ditemukan tes klinis yang dapat mendiagnosa langsung autisme. Diagnosis yang paling baik adalah dengan cara seksama mengamati perilaku anak dalam berkomunikasi, bertingkah laku dan tingkat perkembangannya. Penetapan diagnosis gangguan autism, para klinisi sering menggunakan pedoman Diagnosis and Statistical Manual of Mental ( DSM IV). Anak yang menunjukkan gejala-gejala yang terdapat dalam kriteria DSM IV, harus segera dilakukan assessment pengkajian yang diikuti penegakaan diagnosis. Pengkajian harus dibuat lengkap untuk memberikan gambaran yang jelas mengenai tingkat kelainan anak. Hasil pengkajian menjadi dasar penegakan diagnosis dan perencanaan penanganan anak autis. Hasil diagnosis juga dijadikan pedoman untuk memberikan layanan terapi, model layanan pendidikan dan juga strategi pembelajarannya.

Pelaksanaan diagnosis harus dilakukan oleh orang yang tepat yaitu oleh 
ahli yang terdiri dari psikolog klinis, dokter spesialis anak, psikiater anak. Pelaksanaan diagnosis autis dapat dilakukan melalui pengamatan langsung dan melalui wawancara dengan orang tua. Hasil pengamatan yang telah dilakukan belum dapat dijadikan sebuah kesimpulan yang mutlak dari kemampuan dan perilaku seorang anak. Keterangan dari orang tua mengenai kronologi perkembangan anak adalah hal yang penting untuk menentukan ketepatan hasil diagnosa. Ada beberapa anak autis yang secara sekilas terlihat seperti anak dengan keterbelakangan mental, kelainan perilaku, gangguan pendengaran atau bahkan berperilaku aneh. Untuk itulah sangat penting membedakan antara autis dengan anak tunagrahita sehingga diagnosa yang dihasilkan tepat dan dapat menangani anak autis sejak dini sehingga dapat menentukan terapi yang tepat.

\section{Penanganan Anak Autis}

Penanganan anak autis bertujuan agar perkembangan yang terlambat pada dirinya dapat diatasi sesuåi dengan perkembangan usianya. Semakin cepat mengetahui anak mengalami autis, maka akan semakin cepat pula usaha penanganannya. Deteksi dan intervensi dini sangat penting untuk anak autis sehingga penanganannnya lebih cepat dilakukan dan tidak membutuhkan waktu yang relatif lama.

Intervensi dini secara intensif dan optimal dapar bermanfaat untuk penanganan anak autis yang biasa disebut terapi. Saat yang paling tepat untuk memberikan penanganan pada kasus autis adalah masa balita. Masa balita adalah masa awal untuk mempelajari sesuatu. Anak di bawah usia 3 tahun memiliki otak yang masih bersifat plastis. Pada masa ini sel-sel otak mengalami perkembangan yang sangat pesat, sehingga ada gangguan pada salah satu bagian otak diharapkan dapat tergantikan dengan sel-sel baru.Terapi yang dilakukan berperan sebagai stimulasi bagi perkembangan fungsi sel-sel otak.
Sampai saat ini belum ada obat yang dapat memperbaiki struktur otak atau jaringan syaraf yang kelihatannya mendasari autis. Gejala yang timbul pada anak autis sangat bervariasi, oleh karena itu terapinya sangat individual dan tergantung keadaan dan gejala yang timbul dan harus ditangani secara holistik oleh tim ahli.

Beberapa terapi untuk anak autis diantaranya adalah:

1. Terapi wicara yaitu terapi yang membantu anak melancarkan otot-otot mulut sehingga membantu anak berbicara lebih baik.

Bantuan yang dapat diberikan dalam terapi wicara adalah:

a. Untuk organ bicara dan sekitarnya yang sifatnya fungsional

Bantuan untuk melatih organ bicara yang mengalami kesulitan.

b. Untuk artikulasi atau pengucapan

2. Terapi Biomedik yaitu yaitu penanganan biomedis melalui perbaikan kondisi tubuh agar terlepas dari faktor-faktor yang merusak misalnya keracunan logam berat, allergen dan lain-lain. Terapi biomedik ini mencari semua gangguan tersebut, apabila ditemukan maka harus diperbaiki. Sehingga diharapkan bahwa fungsi susunan saraf pusat bisa bekerja lebih baik sehingga gejala-gejala autism berkurang atau bahkan menghilang. Pemeriksaan yang dilakukan adalah pemeriksaan laboratorik yang meliputi pemeriksaan darah, urin, rambut dan feses. Terapi biomedik melengkapi terapi yang telah ada dengan memperbaiki dari dalam dengan harapan perbaikan akan lebih cepat terjadi.

3. Terapi Makanan

Beberapa anak dengan gangguan autisme pada umumnya alergi terhadap beberapa makanan. Pengalaman dan perhatian orang tua dalam menyiapkan dan mengatur menu makanan serta mengamati gejala yang timbul akibat makanan tertentu sangat bermanfaat dalam menentukan terapi selanjutnya. Terapi diet disesuaikan dengan gejala 
utama yang timbul pada anak. Berikut ini beberapa contoh diet untuk anak autis.

a. Diet tanpa gluten dan kasein

Diet tanpa gluten dan kasein sering direkomendasikan untuk anak dengan gangguan auitsme. Orang tua pada umumnya memulai dengan diet tanpa gluten dan kasein, yang berarti menghindari makanan dan minuman yang mengandung gluten dan kasein.

Gluten adalah protein yang terdapat dalam tumbuhan keluarga rumput misalnya: gandum, dan havermuth. Gluten member kekuatan dan kekenyalan pada tepung terigu. Kasein adalah protein susu. Gluten dan kasein tidak menimbulkan efek samping apabila dikonsumsi oleh orang sehat.

Penurunan gejala autism dengan diet khusus biasanya dapat dilihat dalam waktu antara 1-3 minggu. Apabila diet yang telah dijalankan tidak menunjukkan perubahan atau kemajuan yang berarti, maka diet tersebut dapat dihentikan dan anak dapat diberi makanan seperti sebelumnya.

Makanan yang dihindari adalah makanan yang mengandung gluten yaitu semua makanan yang dibuat dari terigu, havermuth misalnva: roti, mie, kue, kue, cake, biscuit, kue kering, pizza, macaroni, spaghetti, tepung bumbu dan lain-lain.

Produk-produk lain yang perlú diwaspadai untuk dihindari adalah soda kue, baking soda, kaldu instant, saus tomat dan saus yañg lainnya, serta lada bubuk yang dimungkinkan menggunakan campuran tepung terigu. Makanan sumber kasein adalah susu, dan hasil olahannya misalnya es krim, keju, mentega, yogurt, dan makanan yang menggunakan campuran susu.

Ada juga makanan yang tidak diajurkan untuk anak autis yaitu : hasil olahan makanan yang diawetkan misalnya, sosis, kornet, nugget, hotdog, sarden, daging asap, ikan asap, buah dan sayur dalam kaleng.
Makanan sumber karbohidrat yang dianjurkan untuk anak autis adalah beras, singkong, ubi, talas, jagung, tepung beras, tapioca, garut dan umbiumbian. Makanan sumber protein yang dianjurkan adalah susu kedelai, daging segar, ikan segar, unggas, telur, udang, kerang, cumi, tahu, kacang hijau, kacang merah, kacang tolo, kacang mede, kacang kapri. Sayuran segar seperti bayam, brokoli, labu siam, labu kuning, kangkung, tomat, wortel, timun. Buahbuahan segar seperti anggur, apel, pepaya, mangga, pisang, jambu, jeruk, dan semangka.

b. Diet anti yeast/ragi/jamur

Diet makanan ini diberikan kepada anak dengan gangguan infeksi jamur/yeast.

1) Makanan yang perlu dihindari adalah:

a) Makanan yang mengandung gula dan yeast misalnya roti, pastry, biskuit, kue.

b) Makanan hasil olahan seperti daging asap, sosia, hotdog, kornet.

c) Macam-macam saus (saus tomat, saus cabe), monosodium glutamate, macam-macam kecap, macam-macam acar atau makanan yang menggunakan cuka, mayonnaise.

d) Semua jenis jamur segar maupun kering misalnya jamur kuping, jamur merang.

e) Buah yang dikeringkan misalnya kismis, kurma, sale pisang.

f) Sari buah yang diawetkan, minuman berakohol dan semua jenis minuman manis.

2) Makanan yang dianjurkan adalah;

a) Makanan sumber karbohidrat yaitu beras, tepung beras, kentang, ubi, singkong, jagung dan tales.

b) Makanan sumber protein yaitu daging, ikan, udang dan hasil laut lain yang segar.

c) Makanan sumber protein nabati seperti kacang-kacangan seperti kacang hijau, kacang polong. 
d) Semua sayuran segar terutama yang rendah karbohidrat seperti brokoli, kol, kembang kol, bit, wortel, timun, labu siam, bayam, terong, sawi, tomat, buncis, kacang panjang, kangkung, tomat.

e) Buah-buahan segar seperti anggur, apel, pepaya , mangga pisang dalam jumlah terbatas dan tidak berlebihan.

c. Diet untuk alergi dan intoleransi makanan

Pada umumnya anak autis menderita alergi berat. Makanan yang sering menimbulkan alergi adalah ikan, udang, telur, susu, coklat, gandum. Untuk mengatur makanan terhadap anak yang alergi dan intoleransi makanan pertamatama harus mencari sumber penyebabnya dulu. Makanan yang diduga menyebabkan gejala alergi atau intoleransi harus dihindarkan.Jika anak alergi dengan udang, maka semua makanan yang mengandung udang harus dihindarkan.

Cara mengatur makanan untuk anak autis yaitu:

1) Berikan makanan yang seimbang untuk menjamin agar tubuh memperoleh semua zat gizi yang dibutuhkan untuk kepeluan pertumbuhan, perbaikan sel-sel yang rusak, dan kegiatan sehari-hari.

2) Gula sebaiknya dihindari, khususnya bagi yang hiperaktif dan ada infeksi jamur. Fruktosa dapat digunakan sebagai pengganti gula karena penyerapan fruktosa lebih lambat dibanding gula/sukrosa.

3) Minyak untuk memasak sebaiknya menggunakan minyak sayur, minyak jagung, minyak biji bunga matahari, minyak kacang tanah, minyak kedelai.

4) Cukup mengkonsumsi serat, khususnya serat yang berasal dari sayuran dan buah-buahan segar. Konsumsi sayur dan buah 3-5 porsi per hari.
5) Pilih makanan yang tidak menggunakan zat penambah rasa, zat pewarna, dan zat pengawet.

6) Apabila keseimbangan gizi tidak dapat dipenuhi, dapat memberikan suplemen vitamin dan mineral,

7) Perhatikan label pada makanan untuk mengetahui komposisi makanan secara lengkap dan waktu kadaluwarsanya.

8) Memberikan makanan yang cukup bervariasi, sehingga anak tidak bosan.

9) Hindari makanan siap saji, ganti dengan buah dan sayuran segar.

4. Terapi perilaku

Terapi perilaku yaitu terapi yang bertujuan agar perilaku anak menjadi terkendali dan mengerti norma sosial yang berlaku. Fokus penanganan dalam terapi perilaku adalah pemberian reinforcement positif setiap kali anak merespon dengan benar sesuai dengan instruksi yang diberikan. Dalam terapi perilaku ini tidak menerapkan hukuman (punishment) bila anak merespon negatif atau salah atau tidak tepat atas instruksi yang diberikan. Perlakuan ini diharapkan dapt meningkatkan respon positif anak dan mengurangi kemungkinan ia merespon negatif terhadap instruksi yang diberikan.

Prinsip dasar terapi ini adalah Atencendent yang diikuti Behavior, dan diiukti Consequence. Atencendent adalah hal yang mendahului perilaku berupa instruksi yang diberikan oleh seseorang kepada anak autis. Melalui metode pembelajarannya yang terstuktur naka autis diharapkan dapat memahami Behavior (perilaku) apa yang diharapkan dilakukan oleh anak setelah mendapat instruksi, dan perilaku tersebut diharapkan cenderung terjadi lagi bila anak autis memperoleh Consequence (konsekuensi perilaku atau kadang hadiah) yang menyenangkan. Tujuan penanganan ini adalah untuk meningkatkan pemahaman dan kepatuhan anak terhadap aturan. Terapi 
ini pada umumnya mendapatkan hasil yang signifikan bila dilakukan secara intensif, teratur dan konsisten pada usia dini.

Terapi untuk anak autis harus dimulai sejak awal dan harus diarahkan pada hambatan maupun keterlambatan yang secara umum dimiliki oleh setiap anak misalnya komunikasi dan persoalan-persoalan perilaku. Adanya berbagai jenis terapi ini dapat dipilih orang tua, maka sangat penting bagi orang tua penyandang autis untuk memilih salah satu jenis terapi yang dapat meningkatkan fungsionalitas anak dan mengurangi gangguan serta hambatan autisme. Tidak ada satu jenis terapi yang berhasil bagi semua anak. Terapi harus disesuaikan dengan kebutuhan anak berdasarkan pada potensinya, kekurangannya dan tentu saja sesuai dengan minat anak sendiri. Terapi harus dilakukan secara multi disiplin ilmu, misalnya terapi wicara dan terapi okupasi. Tenaga ahli yang menangani anak harus mampu mengarahkan pilihan-pilihan terhadap jenis-jenis terapi yang ada saat ini. Tidak ada jaminan terapi yang telah dipilih oleh orang tua penyandang anak autis dan keluarga dapat berjalan secara efektif. Tentukan salah satu jenis terapi dan laksanakan secara secara konsisten selama 3 bulan. Amati selama 3 bulan tersebut, apabila tidak ada perubahan atau kemajuan yang nyata dapat melakukan perubahan terapi. Orang tua penyandang autis harus melaksanakan bimbingan dan arahan yang diberikan oleh ahlinya secara konsisten. Bila terlihat kemajuan yang signifikan selama 3 bulan maka bentuk intervensi lainnya dapat ditambahkan. Orang tua penyandang autis harus tetap bersikap obyektif dan tanyakan pada para ahli apabila terjadi perubahan-perubahan perilaku lainnya.

\section{Penutup}

Intervensi dini secara intensif dan optimal dapar bermanfaat untuk penanganan anak autis. Pengkajian yang dilakukan pada anak autis sangat penting dalam menegakkan diagnosis serta rencana terapi. Banyak cara dalam program terapi untuk anak autis, tetapi keterlibatan orang tua dalam memahami metode terapi akan meningkatkan hasil yang dicápai. Memahami konsep dasar dari berbagai program terapi adalah langkah utama untuk mendapatkan pilihan terapi.

Sampai saat ini belum ada obat yang dapat memperbaiki struktur otak atau jaringan syaraf yang kelihatannya mendasari autis. Terapi yang dapat dilakukan untuk menangani anak autis diantaranya adalah terapi wicara, terapi biomedik, terapi makanan, dan terapi perilaku. Gejala yang timbul pada anak autis sangat bervariasi, oleh karena itu terapinya sangat individual dan tergantung keadaan dan gejala yang timbul dan harus ditangani secara holistik oleh tim ahli.

\section{Daftar Rujukan}

Eko Handayani. (2008) Anak dengan ganguan Autism. Universitas Terbuka: Jakarta.

Frida Kusumawati. (2013) Kekuatan di Balik Autisme. Intrans. Malang.

Leo Martin. (2010). Financial Planning for Autis Child.Ar-Ruzz Media.

Tuti Soenardi. (2002) Makanan Sehat Anak Autis, Gramedia Pustaka Utama: Jakarta.

Tony Attwood. (2005). Sindrom Asperger. Jakarta: Serambi Ilmu Semesta. 